\title{
Experimental Lead Poisoning and Intestinal Transport of Glucose, Amino Acids, and Sodium
}

\author{
RAUL A. WAPNIR, ${ }^{(71)}$ RAMON A. EXENI, MELINDA MCVICAR, AND FIMA LIFSHITZ
}

North Shore University Hospital, Department of Pediatrics, Manhasset, and Cornell University Medical College', Department of Pediatrics. New York. New York, USA

\begin{abstract}
Summary
Juvenile rats fed a diet containing $1 \%$ lead acetate for 7 weeks, in addition to an impaired growth rate and renal function derangements, suffered malabsorption of glucose and certain amino acids, as assessed by an in vivo perfusion technique. The reduction in glucose absorption ranged between $10 \%$ and $31 \%$ when the carbohydrate was pumped in concentrations of 2-80 mM. This alteration was compatible with a noncompetitive type of transport inhibition. The intestinal absorption of glycine, lysine, and phenylalanine were, respectively, decreased 22,18 , and $15 \%$ when these amino acids were present at 1 mMlevels. Sodium transport was severely reduced $(57.6 \pm 17.9$ (SENI) vs. $124.2 \pm 17.4 \mu \mathrm{Eq} / \mathrm{min} \cdot \mathrm{cm})$ and intestinal mucosa $\left(\mathrm{Na}^{+}-\mathrm{K}^{+}\right)$. ATPase was concomitantly lower in the lead-intoxicated rats (186.4 \pm 19.0 vs $268.4 \pm 29.8 \mathrm{mmol} \mathrm{P} / \mathrm{min} \cdot \mathrm{mg}$ protein). However, this enzyme was not altered in liver and kidney. Furthermore, intestinal mucosa fructose-1,6-diphosphatase, succinic dehydrogenase, pyruvate kinase, and tryptophan hydroxylase were not different in experimental and control animals. These studies substantiate the presence of functional and biochemical abnormalities in the intestinal mucosa of young rats when fed substantial amounts of a soluble lead salt. It is, therefore, reasonable to accept the possibility that physiologic damage occurs in tissues directly subjected to high and persistent levels of a toxic agent, as it occurs in other organs, underscoring the parallelism between transport mechanisms at the renal and intestinal levels.
\end{abstract}

\section{Speculation}

The gastrointestinal symptoms often associated with chronic lead intoxication may be related to physiologic damage of the intestinal mucosa transport mechanisms. Therefore, intestinal mucosa could be considered another primary target organ for lead poisoning, as the kidney, the erythropoietic system, and nervous tissue are known to be.

Lead intoxication in humans has been shown to affect the central nervous system, the hematopoietic system, and the kidneys $(12,13,16,25)$. Susceptibility of red blood cell membrane $\left(\mathrm{Na}^{+}-\mathrm{K}^{+}\right)$-AlPase to lead poisoning has been shown in workers suffering the consequences of excessive exposure to this agent (27). The lead burden in children is the highest among those living in urban ghettos, particularly if they chronically ingest small amounts of wall peelings covered with lead-containing paint (6). This has been called "a preventable childhood discase of the slums" (42).

Numerous investigators have used rats as an animal model of lead intoxication, duplicating alterations in kidncy tubules (24); changes in growth, behavior, and catecholamines (21); brain metabolism $(43,48)$; and damage to the hematopoietic mechanisms $(37,39)$. The oral administration of lead salts has been chosen in most studies, in spite of variable rates of absorption, estimated between $2 \%$ and $10 \%$ of the ingested dose, depend- ing on the dietary status of the animals $(5,19,22,50,51)$. This model, however, provides the closest similarity to the consequences of "pica" in children $(26,42,47,52)$. The relationship between adequacy of diet and the extent of lead poisoning damage has been investigated in experimental studies $(5,22,50)$ and in nutritional surveys of children $(6,38)$.

The purpose of this study was to determine the effects of a chronic intake of lead on the intestinal transport of glueose. amino acids, and sodium, and the possibility of eellular and/or physiologic damage to the intestinal mucosa, in addition to the previously described impaired growth rate and multiple renal function derangements.

\section{MATERIALS AND METHODS}

Male Wistar rats, weighing $60-80 \mathrm{~g}$, in groups of four to eight, were given ad libitum a complete diet $(56)$, containing $1 \%$ lead acetate plus free aceess to water, for a period of 7 weeks. The effective lead intake was estimated to be $60(0) \mu \mathrm{g} / \mathrm{kg} /$ lay. During the last week of the experiments, urine collections were carried out over several 24-hr periods. The experimental animals were housed in metabolic cages and food intake was measured daily. Urinary glucose was determined by a glucose oxidase method (58). Amino acid nitrogen (23), inorganic phosphate (18), and creatinine nitrogen (9) were assayed by colorimetric procedures. Atomic absorption techniques (Perkin-Elmer, model 305A (59)) were applied for lead (32), calcium, and magnesium determinations (3) and flame photometry for sodium and potassium assays $(60)$.

The intestinal absorption of glucose, amino acids, and electrolytes was studied in the rats using an in vivo procedure $(55,56)$. Glucose, in concentrations of 2 to $80 \mathrm{mM}$, labeled with ${ }^{14} \mathrm{C}$ in tracer amounts, plus $1 \mathrm{mM}$ single L-amino acids, including ${ }^{3} \mathrm{H}$ tracer, in both cases at a level about $50,000 \mathrm{dpm} / \mathrm{ml}$, were added to Krebs-Henseleit bicarbonate buffers. Labeled metabolites were purchased from New England Nuclear (61). The tonicity was maintained by adjusting the concentration of $\mathrm{NaCl}$. All chemicals were obtained from Fisher Scientific Co. (62). Polyethylene glycol (PEG), mol wt 3,00(0-3,700, Carbowax $4000(\mathrm{~J}$. T. Baker Co. (6.3)), 6.0 g/liter, served as a nonabsorbable marker and the ratio of its concentration (35) in the buffer to that of the perfusates was used as a correction factor for the calculation of absorption rates. The perfusing liquids were bubbled with $\mathrm{O}_{2}: \mathrm{CO}_{2}, 95: 5$ (Liquid Carbonic (64)), and maintained at $37^{\circ}$ during the experiments. In brief, the animals were anesthetized with $1.2 \mathrm{~g} / \mathrm{kg}$ urethane given intraperitoneally. The abdominal cavity was opened by a midline incision and the small intestine cannulated below the ligament of Treitz. A $20 \mathrm{~cm}-10 \mathrm{ng}$ jejunal segment was utilized and the intestinal contents washed out with two $10-\mathrm{ml}$ portions of warm $0.15 \mathrm{M} \mathrm{NaCl}$. The proximal junction was attached to a peristaltic pump (Harvard Apparatus $(65))$ and perfused at a rate of $0.2(0-0.23 \mathrm{ml} / \mathrm{min}$. The concentration of the glucose or amino acids was determined by isotope dilution computation after counting aliquots in a liquid 
Table 1. Urinary excretion of various metabolites in lead-poisoned rats $(P b)^{\prime}$

\begin{tabular}{|c|c|c|c|}
\hline & \multicolumn{3}{|c|}{ Experimental groups } \\
\hline & $\mathrm{Pb}$ & Control & $P$ \\
\hline Urine volume $(\mathrm{ml} / 24 \mathrm{hr})$ & $10.5 \pm 1.3(34)$ & $4.7 \pm 0.8(20)$ & $<0.001$ \\
\hline Lecad $(\mu \mathrm{g} / 2+\mathrm{hr})$ & $16.5 .8 \pm 33.6(5.5)$ & $9.3 \pm 1.2(23)$ & $<0 .(0) 1$ \\
\hline Glucose $(m g / 24 \mathrm{hr})$ & $10.67 \pm 1.97(2.3)$ & $3.38 \pm 0.78(1.3)$ & $<0.01$ \\
\hline$A A N / c r e a t i n i n e N$ & $0.86 \pm 0.09(22)$ & $0.53 \pm 0.04(14)$ & $<0.01$ \\
\hline Ca/creatinine $N$ & $1.61 \pm 0.24(22)$ & $0.60 \pm 0.15(1.3)$ & $<0 .(01$ \\
\hline$M g /$ creatinine $N$ & $25.1 \pm 10.3(21)$ & $64.1 \pm 13.8(14)$ & $<0.015$ \\
\hline P/creatinine $N$ & $1.16 \pm 0.38(21)$ & $2.46 \pm 0.70(14)$ & NS \\
\hline Sodium $(\mu \mathrm{Ey} / 2+\mathrm{hr})$ & $694 \pm 79(38)$ & $1.255 \pm 166(16)$ & $<0.01$ \\
\hline Potassium $(\mu \mathrm{E} \mathrm{y} / 2+\mathrm{hr})$ & $1.06 .5 \pm 16.3(35)$ & $2.095 \pm 209(11)$ & $<0 .(0) 1$ \\
\hline
\end{tabular}

'Means \pm SEM. Number of assays in parenthesis. Glucose oxidase was used for the determination of glucose (58); colorimetric methods for the assay of amino acid nitrogen (AAN) (23), inorganic phosphorus (18), and creatinine $N(9)$; atomic absorption spectrophotometry for lead (32), calcium, and magnesium (3); and flame photometry for sodium and potassium. The significance of the difference of means was determined by a nonpaired Student's t-test (17).

scintillation counter (Beckman, model LS-203 (66)) with a precision better than $0.7 \%$ and an efficiency above $50 \%$ for ${ }^{14} \mathrm{C}$, or $20 \%$ for ${ }^{3} \mathrm{H}$.

At the end of the perfusion, a 30 cm-segment of the small intestine, distal to the camnulated portion, was excised, washed twice with ice-cold $0.15 \mathrm{M} \mathrm{NaCl}$, and the intestinal mucosa scraped with a glass slide and immediately homogenized in a glass homogenizer with a Teflon pestle (Tri-R Instruments (67)) with four volumes of $(0.15 \mathrm{M} \mathrm{NaCl}$. The homogenate was centrifuged at 7()()$\times g$ and frozen at -5()$^{\circ}$. A similar treatment was applied to kidney and liver specimens. The homogenates were thawed for the determination of total ATPase and $\left(\mathrm{Nal}^{+}-\mathrm{K}^{+}\right)$ATPase (31), fructose-1,6-diphosphatase (36), succinic dehydrogenase (8), pyruvate kinase (10), tryptophan hydroxylase (55), and protein $(34)$.

In other experiments, the integrity of the intestinal mucosa was assessed by perfusing the animals as indicated above with |"C $^{1 .} \mathrm{PE}$ G or with $\left.\alpha\right|^{1.4} \mathrm{C} \mid$-aminoisobutyric acid $(\mathrm{AIB})$ in tracer levels added to the standard amounts of the marker or the amino acid in the buffer. After a 2 hr perfusion, blood specimens were taken from the suborbital sinus of the rats and deproteinized with an equal volume of $2 \mathrm{M} \mathrm{HClO}_{4}$. The supernatant was counted in a liguid scintillation spectrometer $(56)$. The $\left.{ }^{1+4} \mathrm{C}\right]$ AlB uptake of the intestinal mucosa was determined by measuring the radioactivity taken up by that tissue and expressing it as related to protein content, as published previously (56). The significance of the differences between means was assessed applying a two-tailed Student's t-test (17).

\section{RISSULTS}

Rats fed lead acetate $(\mathrm{Pb})$ failed to grow at the same rate as controls $(C)$ fed the same diet without leat. At the end of the lest period the experimental animals weighed $128.0 \pm 4.2 \mathrm{~g}$ vs. $177.8 \pm 8.3 \mathrm{~g}$ for the C group (means \pm SLN $32 \mathrm{~d}$.f...t $=5.35$. $P<0.001)$. Comparable weight differences were observed from the first week of the experiments. This weight discrepancy was not dee to at reduced food or fluid intake. There was no observable diarrhea. However, the food efficiency in the $\mathrm{Pb}$ rats was far below that exhibited by the $C$ animals (expressed as grams of weight gained by $100 \mathrm{~g}$ of food: $\mathrm{Pb}: 8.02 \pm 0.57, \mathrm{C}: 12.89 \pm$ $1.65 .10(1 . f ., t=2.79, P<0.02)$. As described carlier by Gover (24), Pb rats had aminoaciduria and glycosuria associated with polyuria. Noreover, we found that the rats treated with $\mathrm{Pb}$ had proportionally higher losses of calcium. In contrast, the renal excretion of sodium, potassium, and magnesium was reduced in the experimental animals (Table 1). The results in this study were expressed in several instances in terms of creatinine nitrogen to compensate for weight differences, although the validity of data expressed in this fashion has been questioned in human clinical chemistry $(4+)$.

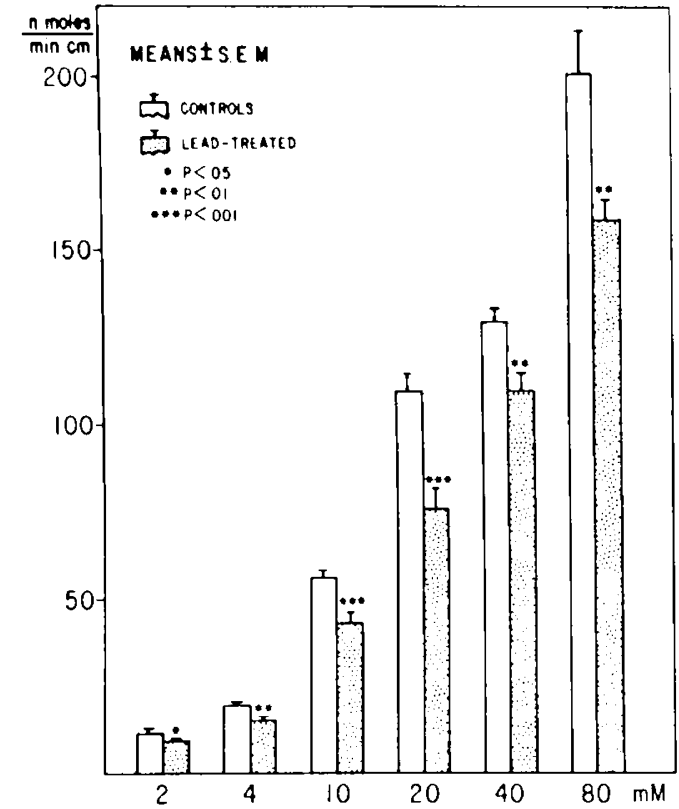

Fig. 1. Intestinal absorption of glucose in Pb-poisoned rats and controls according to the in vivo procedure described in the text. lach bar represents the means of individual determinations of glucose concentrations in the fractions collected from six to eight animals.

Glucose intestinal absorption was significantly reduced in $\mathrm{Pb}$ rats over the whole range of concentrations of glucose values (Fig. 1). The kinetics of this phenomenon was compatible with a noncompetitive type of inhibition (Fig. 2). The representation of $V$ vis. V/S and $S / V$ vs. $S$ have been shown to be better graphic transformations than the Lineweaver-Burk plot (15).

At the same time, the intestinal transport of lysine, glycine, and phenylalanine was inhibited, but other neutral amino acids such as AlB, tyrosine, and tryptophan were not affected (Table 2). A simultancous severe reduction of sodium intestinal absorption was observed in the Pb rats, but potassium influx across the small intestinal mucosa was not impaired. This finding was concomitant with a decrease in the levels of small intestinal mucosa $\left(\mathrm{Na}^{+}-\mathrm{K}^{+}\right)$-ATPase measured in homogenates obtained from the jejunum immediately contiguous to the perfused segment. In contrast, total and $\left(\mathrm{Na}^{+} \mathrm{K}^{+}\right)$-ATPase activity of kidney and liver bomogenates was the same for $\mathrm{Pb}$ and $\mathrm{C}$ animals (Fig. 3). The alteration in the enzymatic capability of the intestinal mucosa appeared to be narrowly restricted, since four other enzymes present in that tissue and representative of key metabolic pathways in carbohydrate and amino acid metabolism were not altered in the Pb-poisoned rats (Fig. 4). 
It was considered possible that those alterations in intestinal transport could be caused by nonspecific damage of the intestinal mucosa by $\mathrm{Pb}$. Such damage could result in leakage of the marker, "C-labeled PEG, into the circulation. However, radioactivity in the blood of both $\mathrm{Pb}$ and $\mathrm{C}$ rats was indistinguishable from background (Table 3 ). In addition, the blood-to-lumen passage of glucose, measured by the appearance of glueose in collected perfusates when no sugar was added to the KrebsHensele te buffer, was the same in $\mathrm{Pb}$ and $\mathrm{C}$ animals, and negligible when compared with lumen-to-blood absorption rates. On the other hand, the lumen-to-blood passage of $\left[^{14} \mathrm{C}-\mid \mathrm{AIB}\right.$ wals higher in the Pb-poisoned rats. Furthermore, a higher amount of radioactivity was present in the intestinal mucosa, suggesting a certain extent of increased permeability to solutes of small molecular weight. However, no ultrastructural alterations could be observed in electron microscopy preparations of the intestinal mucosa of $\mathrm{Pb}$ rats after 7 weeks of dietary treatment (53).

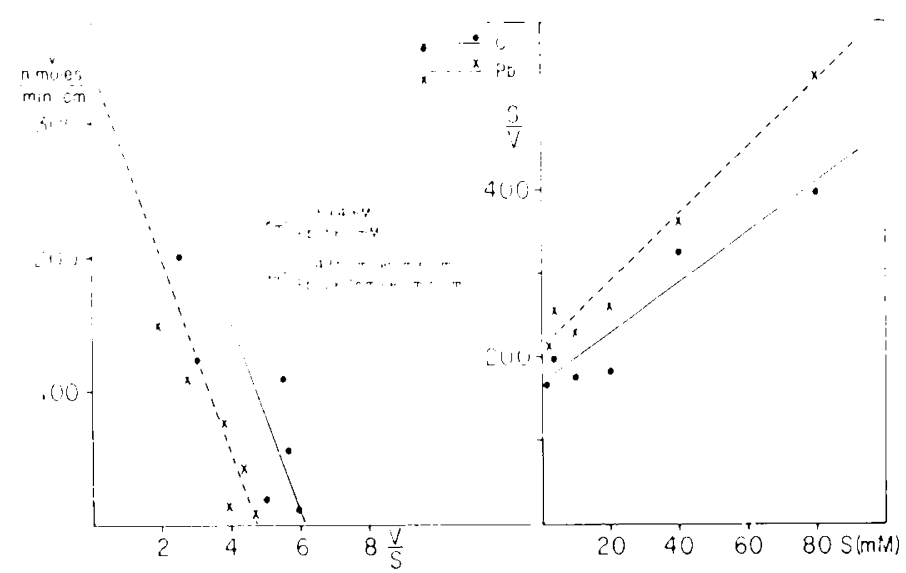

Fig. 2. Kinctics of the intestinal transport of glucose in Ph-poisoned and control rats determined by the in vivo technique detailed under Materials and Methods. By mathematical extrapolation. the statistically identical $K_{m}$ values corresponding to the Pb-peisoned and control animals were 56.1 and 59.4 mM, respectively. The corresponding, significantly different. $V_{11}$ values were 267 and $4.35 \mathrm{mmol} / \mathrm{min} \cdot \mathrm{cm}$, respectively. These data indicated a noncompetitive inhibition of glueose transport in Ph-poisoned rats. For each point, six to eight animals were used in the perfusion experiments.

Table 2. Intestinal transport of amino acids and clectrolytes in lead-poisoned rats $(P b)^{\prime}$

\begin{tabular}{|c|c|c|c|c|}
\hline \multirow{3}{*}{$-\quad-\quad----\ldots$} & \\
\hline & \multicolumn{4}{|c|}{ Experimental groups } \\
\hline & & $\mathrm{Pb}$ & Control & $P$ \\
\hline \multicolumn{5}{|l|}{ Amino acids } \\
\hline Lysinc & $3.21=$ & $\pm 0.17(4$ & $3.94 \pm 0.22(20)$ & $<0.02$ \\
\hline Glycinc & 2.76 & $\pm 0.20(4$ & $3.54 \pm 0.26(20)$ & $<0.05$ \\
\hline Phenylablanine & 3.35 & $\pm 0.19(4$ & $3.94 \pm 0.16(24)$ & $<0.05$ \\
\hline Tyrosine & $3.96=$ & $\pm 0.12(6$. & $+.12 \pm 0.18(32)$ & NS \\
\hline$A I B$ & 1.76 & $\pm 0.13(4$ & $1.77 \pm 0.12(18)$ & NS \\
\hline Tryptophan & 5.52 & $\pm 0.21(3$ & $5.22 \pm 0.24(20)$ & NS \\
\hline \multicolumn{5}{|l|}{ Electrolytes } \\
\hline Sodium & 57.6 & $\pm 17.9(9$ & $124.2 \pm 17.4(48)$ & $<0.01$ \\
\hline Potassium & 5.78 & $\pm 0.88(9$ & $7.30 \pm 0.80(48)$ & NS \\
\hline
\end{tabular}

1 Mean \pm SEM of the transport rates obtained in an in vive perfusion system (see texi and Reference 56), using Krebs-Henseleit bicarbonate buffers with $1 \mathrm{mWl}$ concentration of the amino acids. The results are expressed in nanomoles per min per em for the amino acids and in microequivalents per min per em for electrolytes. Number of determinattions in parenthesis. A nompaired Student's $t$-test was applied to establish the significance of the differences (17). AIB: $\alpha$-aminoisobutyric acid.

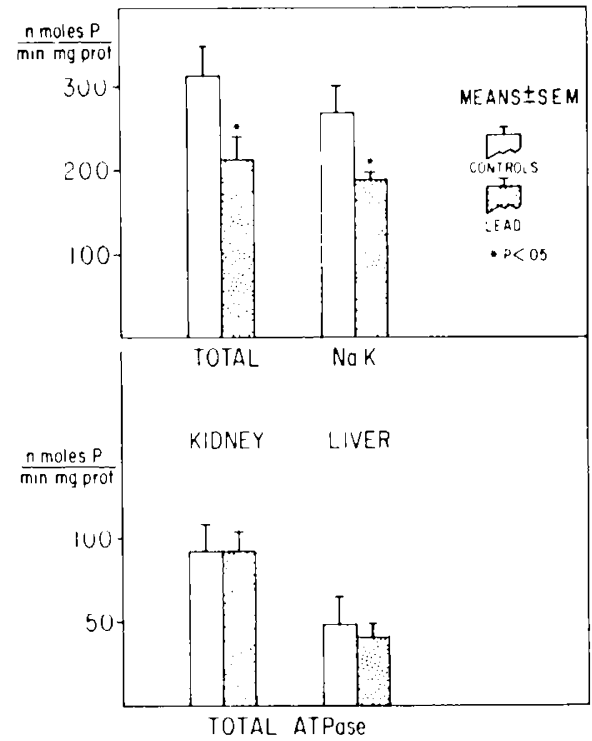

Fig. 3. $\left(\mathrm{Na}^{+}-\mathrm{K}^{+}\right)$-ATPase and total ATPase in the intestinal mucosa, kidney, and liver of Pb-poisoned rats, after 7 weeks on the diet, and their controls, determined as detailed in Reference 31 . The $\left(\mathrm{Na}^{+}-\mathrm{K}^{+}\right)$-ATPase in the kidney and liver of boh groups of animals, not shown here, was indistinguishable. Eight rats used in each group.

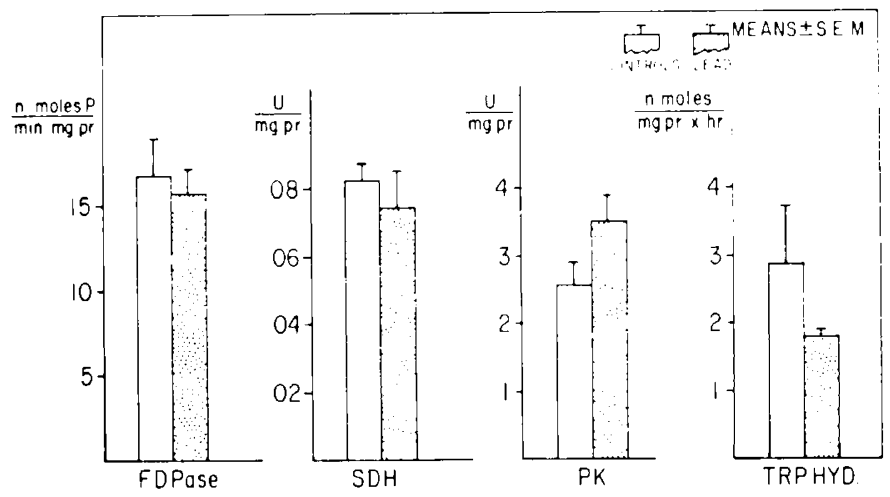

Fig. 4. Intestinal mucosa enzymatic activity in Pb-poisoned and control rats. FDPase: fructose-1, (n-diphosphatase; SI)H: succinic dehydrogenase; PK: pyruvate kinase; TRP.MYD.: tryptophan hydroxylase. In none of these cases there wals a significant difference between the two groups. Duration of treatment and number of rats, as in Figure 3.

\section{DISCUSSION}

Transport of solutes across membranes is a complex phenomenon which associates the passage of an clectrolyte, sodium, with that of glucose and amino acids $(2,49,52)$. In this context, $\left(\mathrm{N}^{+}{ }^{+}-\mathrm{K}^{+}\right)$-ATPase has been shown to play a key role in sodium and potassium transport in many tissues. including the intestinal mucosa $(11,40)$. Our studies, revealing a concomitant impairment of intestinal transport of glucose. certain neutral amino acids, and sodium, with an inhibition of intestinal mucosa $\left(\mathrm{Na}^{+}-\right.$ $\mathrm{K}^{+}$)-ATPase after prolonged lead intake, confirm the interrelattionship between those factors in an in vivo experimental model.

The effects observed at the intestinal mucosa level oceurred without measurable changes of the $\left(\mathrm{Na}^{+}-\mathrm{K}^{+}\right)-\mathrm{ATP}$ ase in the kidney, or the liver. The kidney, however, showed conspicuous alterations in the excretion of electrolytes and amino acids. as well as glucose. A breakdown in the tubular resorption of these substances has generally been considered to be the cause of these abmomalities. Nore recently, the kead-induced defect in urineconcentrating ability has been attributed to an inadequate 
Table 3. Assessment of intestinal mucosa integrity,

Experimental groups

\section{Test}

A. Lumen-to-blood [1+C]PEG leakage

B. Blood-to-lumen glucose influx $(\mathrm{nmol} / \mathrm{min} \cdot \mathrm{cm})$

C. Lumen-to-blood $\left.\left.\right|^{14} \mathrm{C}\right] \mathrm{AIB}$ passage (mean $\%$ of buffer activity attained in blood)

D. $\left[{ }^{14} \mathrm{C}\right] \mathrm{A}$ IB uptake by intestinal mucosa $(\mu \mathrm{Ci} / \mathrm{g}$ protein)

\begin{tabular}{|c|c|c|c|}
\hline & $\mathrm{Pb}$ & Control & $P$ \\
\hline & Background & Background & NS \\
\hline & $0.352 \pm 0.175$ & $0.425 \pm 0.227$ & NS \\
\hline uffer activ- & $0.20 \pm 0.02$ & $0.15 \pm 0.02$ & $<0.00) !$ \\
\hline
\end{tabular}

$0.0 .456 \pm 0.0045$

$0.0263 \pm 0.0(063$

$<0.05$

${ }^{1}$ Four animals in each group were used for every test. Results are expressed as the means \pm SEM. Test $A$ was carried out with a Krebs-lHenseleit buffer containing $6.0 \mathrm{~g} /$ liter polyethylene glycol (PEG) and $50,000 \mathrm{dpm} / \mathrm{ml}$ of $\left.\mid 1,2-{ }^{14} \mathrm{C}\right]$ PEG. Test B was performed with a glucose-free KrebsHenseleit buffer, perfused for 2 hr under the conditions described in Materials and Methods. Tests $\mathrm{C}$ and $\mathrm{D}$ were conducted with 1 mM $\alpha$ aminoisobutyric acid $(\mathrm{AIB})$ and tracer amounts of $\left[{ }^{14} \mathrm{C}\right] \mathrm{AIB}$.

release of ADH (29). Correlation of membrane transport defects in the gut and the kidney has been demonstrated in the human diseases, cystinuria, Lowe's syndrome, and Hartnup's (54). It is, therefore, not unreasonable that a toxic agent such as lead may have simultaneous effects on transport mechanisms in two of the organs which regulate exchanges of the inner milieu with the environment. At any rate, other factors need to be taken into consideration, namely, competition between ions for active sites in the proximal tubule.

In our experiments, the biochemical and physiologic damage of the intestinal mucosa could be detected before gross alteration of small intestinal cells observable by electron microscopy. However, biochemically, the small intestinal mucosa appeared to be sensitive to lead at an earlier stage than the kidney. Goyer (24) has shown that 10 weeks under comparable conditions were a minimum required to indece marked mitochondrial swelling in the proximal tubule of the kidney.

The observation that the impairment of glucose transport was compatible with a noncompetitive type of inhibition is understandable under the assumption that the heavy metal produces a nonspecific alteration in the avatiability of active sites for the translocation of glucose and certain amino acids, rather than a competitive binding of the inhibitor. presumably lead, to specific active sites for those substances. The circumstances that not all neutral amino acid absorption rates were equally reduced can be interpreted in the context of these metabolites sharing common transport mechanisms and simultaneously possessing specific membrane carriers which are distinct from the former and exhibit different functional properties. This possibility has been discussed in previous studies considering competition among amino acids at the intestinal mucosa level $(5.5,57)$.

The failure of the $\mathrm{Pb}$ rats $\mathrm{to}$ grow at the same rate as the $\mathrm{C}$ animals was not due to a decreased food intake. In fact, rats aceepted readily the lead acetate ration. The sweet taste of this salt. long ago known as "sugar of lead" ( 45$)$ contributed to undiminished intake in the experimental group. Therefore, their lagging weight gain could be related either to a deficient renal function. to a malabsorption phenomenon, or to interference by lead of other key metabolic mechanisms (12,16, 25, 27). Naturally, a combination of these possibilities should be a primary consideration. The deficient development of these animals carries a strong resemblance to the human condition of juvenile lead poisoning $(6,13,25)$, as well as to other forms of kidney disease often associated with failure to grow, such as renal tubular acidosis $(41)$ and chronic uremia (28). In humans, gastrointestinal symptoms have been described in the majority of a group of 58 children suffering an increased lead burden (47). The alterations of solium transport, experimentally demonstrated in these studies, may have induced water flux abnormalities which could be responsible for some of the intestinal clisturbances associated with lead ingestion. There have been also observations of radiologic evidence of duodenal ulcerations in children known to have ingested lead-containing. nonfood substances (14).

In regard to the dose relationship in animal models of lead poisoning, it should be noted that the tolerance of rats is at least
10 times that of humans (4). Even in the absence of leadcontaining paint, a child in an urban enviromment may inhale and ingest amounts of that heavy metal far in excess of the "maximum daily permissible" lead intake (33). The conditions in this study offer a reasonable parallel to hazards many children are exposed to. Household dust can contain over $1 \%$ of lead (33) and be the main vector in cases of kead poisoning $(33,46)$. Such an exposure can be aggravated by a rate of lead absorption as high as $50 \%$ in children (1) and newborn rats (30), which exceeds by an order of magnitude the proportion of lead retained by adult mammals $(19,50,51)$. It is, then, reasonable to accept the possibility that physiologic and biochemical damage occurs in tissues directly subjected to high and persistent levels of a toxic agent, as it occurs in other organs. As little as $1 \mathrm{mg}$ lead/day has been considered enough to cause lead poisoning in children over a 6-month period (25). This amount would correspond to 7()$-80 \mu \mathrm{g} / \mathrm{kg} /$ day for a $12-14-\mathrm{kg}$ child. In consequence, the $6(0) \mu \mathrm{g} / \mathrm{kg} / \mathrm{day}$ ingested by the rats is a conservative scaling down of dosiages.

The pervalsiveness of the biologic injuries which lead can cause has been recently extended to possible intratuterine and neonatal brain damage due to drinking water containing high concentrations of the heavy metal. A study conducted in Scotland associated this parameter in the water supply avalable to mothers during gestation, and their infants during the first year of life, with mental retardation in youngsters. In a remarkable response to a public health hazard, the city of Glasgow adopted special water treatment precautions in an effort to decrease lead contamination (7).

It is conceivable, therefore, that malabsorption manifestations and biochemical changes in the intestinal mucosa observed in $\mathrm{Pb}$ rats may provide a clue to the nature of some of the physiologic abnormalities present in humans chronically poisoned with lead, particularly carly in life.

\section{CONCLUSION}

A diet containing $1 \%$ lead acetate fed for 7 weeks to young rats produced an impaired intestinal absorption of glucose and certain amino acids, with a concomitant reduction of sodium transport. Intestinal mucosa $\left(\mathrm{Na}^{+}-\mathrm{K}^{+}\right)$-ATPase was lower in lead-intoxicated animals, although this enzyme was not altered in kidney and liver, suggesting the intestinal mucosa as a primary target organ in lead poisoning.

\section{REFERIENCES AND NOTES}

1. Alexander, F. W.: The uptake of lead by children in different enviromments. Environ. Health Perspect. 7: 155 (1974).

2. Alvarado, F., Torres-Pinedo, R., Mateu, L., and Robinson, J. W.: Counter transport between sugars and amino acids in rabbit ileum. Fed. Eur. Biochem. Sor. Lett., 8: $153(1970)$.

3. Analytical Methods for Atomic Absorption Spectrophotometry (Perkin-Elmer Co., Norwalk, Conn.).

4. Arena, J. M.: Poisoning, Ed. 3, p. 21 (Charles C Thomas, Springficld, Ill. 1974).

5. Bacrnstein, H. D., and Grand, J. A.: The relation of protein intake to lead 
poisoning in rats. J. Pharmacol. Exp. Ther.. 74: 18 (1942).

6. Barltrop, D., and Killala. N. J. P.: Factors influencing exposure of children to lead. Arch. Dis. Childhood, 44: 470 $(1969)$.

7. Beattic, A. D.. Moore, M. R.. Goldberg, A.. Finlayson, M. J. W.. Graham, J. F. Mackie, E. M., Main, J. C.. McLaren, D. A., Mfurdoch, R. M.. and Stewart, G. T.: Role of chronic low-level lead exposure in the atetiology of mental retardation. Lancet $i: 589(1975)$

8. Bonner. W. D.: Succinic dehyctrogenase. In: S. P. Colowick and N. (). Kaplan: Methods in Enzymology, Vol. 1, p. 722 (Academic Press, New York, 1955)

9. Bonsnes, R. W., and Taussky, H. H.: On the colorimetric determination of creatinine by the Jaffe reaction. J. Biol. Chem.. 158: 581 (19.45).

10. Bucher. I., and Pfleiderer, G.: Pyruvate kinase. In S. P. Colowick and N. O. Kaplan: Methods in Enzymology, Vol. 1, p. 435 (Academic Press. New York, 1955)

11. Charney, A. N., Kinsey, M. D., Myers, L., Giannella, R. A., and Gots, R. E.: $\left(\mathrm{Na}^{+}-\mathrm{K}^{+}\right)$-atetivated adenosine triphosphatase and intestinal electrolyte transport. J. Clin. Invest., 56: 6.53 (1975).

12. Chisolm. J. J.: Aminoaciduria as a manifestation of renal tubular injury in lead intoxication and a comparison with patterns of aminoaciduria seen in other diseases. J. Pediat., 60: 1 (1962)

13. Chisolm, J. J., and Kaplan, E.: Lead poisoning in childhood: Comprehensive management and prevention. J. Pediat.. 73: 942 (1968).

14. De Rosit, S.: Personal communication. (These observations were conducted at the Hospital de Niños, Buenos Aires, Argentina.)

15. Dowd, J. E., and Riggs, D. S.: A comparison of estimates of MichaclisMenten kinetic constants from various lincar transformations. J. Biol. Chem., 240: $86,3(1965)$.

16. Lienberg. G., Rinsler, S. S., and Fish, B. G.: Lead neuropathy and sickle cell discase. Pediatrics, $54: 438(1974)$

17. Fisher, R. A.: Statistical Methods for Research Workers, Ed. 13, pp. 114-174 (Hafner. New York, 1958).

18. Fiske, C. 11., and SubbaRow, Y': The colorimetric determination of phosphorus. J. Biol. (hem. 66: 375 (1425).

19. Garber, B. T., and Wei, E.: Influence of dietary factors on the gastrointestinal absorption of lead. Toxicol. Appl. Pharmacol., 27: 685 (1974)

20. Goldner, A. M.: Sodium-dependent sugar transport in the intestine. Metabolism, 22: 649 (1973).

21. Golter, M., and Michaclson, I. A.: Growth, behavior and brain catecholamines in kead-exposed neonatal rats: A reappraisal. Science, 187: 354 (1975).

22. Gontzea, I., Sutzesco, P., Cocora, D., and Lungu, D.: Importance de l'apport de proteines sur la resistance de lorganisme à l'intoxication par le plomb. Arch. Sci. Physiol. (Paris), 18: 211 (1964).

23. Goolwin, J. F.: On the measurement of urinary amino nitrogen with 1-fluoro2.4-dinitrobenzene. Clin. Chim. Acta, 21:231 (1968).

24. Goyer, R. A.: The renal tubule in lead poisoning. 1. Mitochondrial swelling and aminoaciduria. Lab. Invest.. 19: 71 (1968).

25. Goyer, R. A.: Lead toxicity: A problem in environmental pathology. Amer. J Pathol.. 04: 167 (1971)

26. Guince, V. F.: Pica and lead poisoning. Nutr. Rev.. 29: 267 (1971).

27. Hassan, J., Vihko, V., and Hernberg. S.: Deficient red cell membranc (Nat$\mathrm{K}^{+}$)-ATPase in lead poisoning. Arch. Environ. Health. 14: 313 (1967).

28. Holliclay, M. A. Polter, D. B., and Dobrin, R. S.: Treatment of renal failure in chiluren. In: C. M. Edelmann. Jr.: Symposium on Pediatric Nephrology. Pediat. Clin. N. Amer., /8: 613 (1971).

29. Johnson, D. R.: Urinary concentrating defect in lead-exposed rats. Fed. Proc. 3.5: $371(1976)$

30. Kostial, K., Simonovic, I.. and Pisonic, M.: Lead absorption from the intestine in newborn rats. Nature, 23.3: $564(1971)$

31. Kramer, 11. J., Backer, A., and Kruck, F.: Inhibition of intestinal $\left(\mathrm{Na}^{+}-\mathrm{K}^{+}\right)$ATPase in experimental uremia. Clin. Chim. Acta, 50: 13 (1974).

32. Kopito. L., and Schwachman, H.: I)etermination of lead in urine by atomic absorption spectroscopy using coprecipitation with bismuth. J. Lab. Clin. Med., 70: $326(1967)$

33. I.epow, M. L.. Bruckman, L., Gillette, M., Markowitz, S., Robino, R. and Kapish, J.: Investigations into sources of lead in the environment of urban children. Environ. Res., 10: $415(1975)$.

34. Lowry, O. H.. Roscbrough, N. J., Farr, A. L., and Randall, R. J.: Protein measurement with the Folin phenol reagemt. J. Biol. Chem., 193: 265 (195!).

35. Malawer, S. J., and Powell, D. W.: An improved turbidimetric analysis of polyethylene glycol utilizing an emulsifier. Gastroenterology, 53: 250 (1967).

36. McGilvery, R. W.: Fructose-1,6-diphosphatase. In: S. P. Colowick and N. O.
Kaplan: Methods in Enzymology, Vol. 2, p. 543. (Academic Press, New York, 1955)

37. Millar, J. A., Battistini, V., Cumming, R. L. C.. Carswell, F. and Goldtherg. A: Lead and $\delta$-aminolaevulinic acid dehydratase levels in mentally retarded children and in kead-poisoned suckling rats. Lancet, ii: 695 (1970).

38. Mooty, J., Forrand, C. F., and Harris, P.: Relationship of diet to lead poisoning in children. Pediatrics, 55: 6.36 (1975).

39. Morgan, J. M., and Burch, H. B.: Erythrocyle delta-iminolevulinic acid dehydratase activity as a measure of lead exposure. J. Lab. Clin. Med., 85 $746(1975)$.

40. Murer, H., Sigrist-Nelson, K., and Hopfer. U.: On the mechanism of sugar and amino acid interaction in intestinal transport. J. Biol. (hem.. 250: 739) (1975).

41. Nash, M. A., Torrado, A. D., Greifer, I., Spitzer, A., and Edelmann, C. M.: Renal tubular acidosis in infants and children. J. Pediat., 80): 738 (1972).

42. Oberle, M. W.: Lead poisoning: A preventable childhood disease of the slums. Science. 165: 991 (1969).

43. Patel, A. J., Michaclson, I. A., Cremer, J. E., and Balazs, R.: The metabelism of $\left({ }^{1+} \mathrm{C}\right)$ glucose by the brains of suckling rats intoxicated with inorganic kead. J. Neurochem., 22: 581 (1974).

44. Paterson. N.: Relative constancy of 24-hour urine volume and 24-hour creatinine output. Clin. Chim. Acta, /8: 57 (1967).

45. Parkes, G. D., and Mellor, J. W.: Modern Inorganic Chemistry, p. 710 (L.ongmans. Green and Co.. London, 1946).

46. Perkins, K. C., and Oski, F. A.: Elevated bleod lead in a 6-month-old breastfed infant: The role of newsprint legs. Pediatries, $57:+26(1976)$.

47. Pueschel, S. M., Kopito, L., and Schwachman, H.; Children with an increased lead burden-A screening and follow up study. J. Amer. Med. Ass., 222: 462 (1972).

48. Satuerhoff, M. W.., and Michaclson, I. A.: Hyperactivity and brain catcoholamines in lead-exposed developing rats. Science, $182: 1022$ (1973).

49. Schultz, S. G.: The interaction between sodium and amino acid transport across the brush border of rabbit ileum: a plausible molecular model. In: D. C. Testeson: The Molecular Basis of Membranc Function, pp. 401-420 (Prentice Hall, Englewood Cliffs, N. J., 1969).

50. Six, K. M., and Goyer, R. A.: Experimental enhancement of lead toxicity by low dictary calcium. J. Lab. Clin. Ned., 76: 933 (1970)

51. Snowdon, C. T., and Sanderson. B. A.: Lead pica produced in rats. Science. 183: $92(1474)$.

52. Spencer, R. P.: Intestinal absorption of amino acids. Amer. J. Clin. Nutr. 22: $292(1969)$.

53. Teichberg, $S$ : : Personal communication

54. Thier, S. O., and Alpers, D. H.: Disorders of intestinal transport of amine acids. Amer. J. Dis. Child., 117: 13 (1969).

55. Wapnir. R. A.. Hawkins, R. L., and Lifshitz, F.: Hyperaminoaciduria effects on intestinal transport of related amino acids. Amer. J. Physiof., 223: 788 (1972).

56. Wapnir, R. A., and Lifshitz, F.: Absorption of amino acids in malnourished rats. J. Nutr., 104: 843 (1974)

57. Wapnir, R. A., and Lifshitz, F.: L-phenylalanine interactions with structurally-related substances at the intestinal mucosa. Biochem. Med., 11: 370 (1974).

58. Washka, M. E., and Rice, E. W.: Determination of glucose by an improved "Glucostat" procedure. Clin. Chem., 7: 542 (1961)

59. Norwalk. Conn.

60. Flame photometer, model 143. Instrumentation Labs, Boston, Malss.

61. Boston, Mass.

62. Fairlawn, N. J

63. Phillipsburgh, N. J.

64. Chicago, Ill.

65. Millis, Mass.

66. Fullerton, Calif.

67. Rochville Centre, N. Y

68. We thank Dr. Saul Teichberg for electron microscopy observations and Susan A. Moak for technical assistance.

69. This study was presented, in part, at the 59th annual mecting of the Federation of American Societies of Experimental Biology, Atlantic City, New Jersey, April 197.5 .

70. The present address of Dr. R. A. Exeni is: Hospital de Ninos. San Juste (Buenos Aires), Argentina.

71. Requests for reprints should be addressed to: R. A. Wapnir, Ph.D., Department of Pediatrics, North Shore University Hospital, Manhasset, N. Y. 11030 (USA).

72. Received for publication May 21, 1976

73. Accepted for publication August 12, 1976. 